\title{
Removal of a melee weapon forgotten in the orbital cavity: case report
}

\author{
Remoção de arma branca esquecida \\ em órbita: relato de caso
}

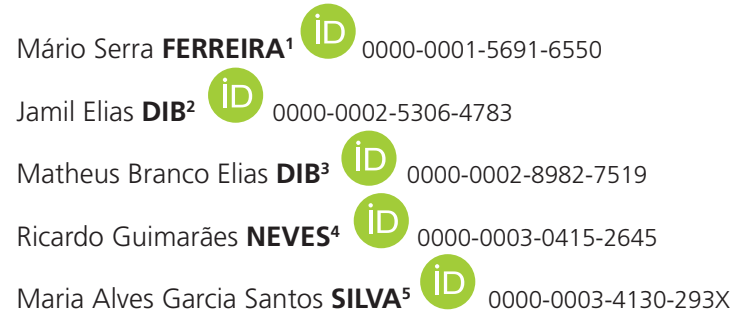

\section{ABSTRACT}

Facial aggressions perpetrated with melee weapons cause injuries that are difficult to treat. Possible aesthetic-functional sequels can cause irreparable damage to the patients. This study presents a case of a patient who suffered physical aggression resulting in a fracture caused with a knife in the orbital cavity that had not been diagnosed during emergency healthcare. After nine months of the primary trauma, the patient developed a fistula in the eyelid region due to infection. The surgery for removal of the foreign body was performed under general anaesthesia and the object was removed through subtarsal approach without causing structural damage to the patient. After satisfactory tissue healing, the treatment was discontinued.

Indexing terms: Orbit. Traumatology. Wounds and Injuries

\section{RESUMO}

As agressões faciais oriundas de arma branca constituem lesões de difícil tratamento. As possíveis sequelas estético-funcionais podem acarretar danos irreparáveis ao paciente. Este trabalho tem como escopo apresentar um caso de um paciente que sofrera agressão física resultando em fratura por arma branca dentro da cavidade orbitária que não fora diagnosticada durante o atendimento primário emergencial. Após nove meses do trauma primário, o mesmo desenvolveu fístula na região palpebral devido a infecção. A cirurgia para remoção do corpo estranho foi realizada sob anestesia geral e o objeto removido através do acesso subtarsal sem acarretar danos estruturais ao paciente. Após a cicatrização tecidual satisfatória, paciente recebeu alta do tratamento.

Termos de indexação: Órbita. Traumatologia. Ferimento por arma branca.

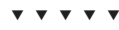

${ }^{1}$ Centro Universitário de Anápolis-UniEVANGÉLICA, Curso de Odontologia, Departamento de Cirurgia e Traumatologia Buco-Maxilo-Facial. Av. Universitária km 3,5, Cidade Universitária, 75083-515, Anápolis, GO, Brasil. Correspondence to: MS FERREIRA. E-mail: <mario.ferreira@ docente.unievangelica.edu.br>.

2 Hospital Estadual de Urgências de Anápolis Dr. Henrique Santillo. Departamento de Cirurgia e Traumatologia Buco-Maxilo-Facial. Anápolis, GO, Brasil.

${ }^{3}$ Clínica Privada. São Paulo, SP. Brasil.

${ }^{4}$ Clínica Privada. Anápolis, GO, Brasil.

${ }^{5}$ Universidade Federal de Goiás, Faculdade de Odontologia, Departamento de Ciências Estomatológicas. Anápolis, GO, Brasil.

$\checkmark \nabla \nabla$

How to cite this article

Ferreira MS, Dib JE, Dib MBE, Neves RG, Silva MAGS. Removal of a melee weapon forgotten in the orbital cavity: case report. RGO, Rev Gaúch Odontol. 2020;68:e20200008. http://dx.doi.org/10.1590/1981-86372020000082019-0004 


\section{INTRODUCTION}

Facial injuries due to physical aggression in underdeveloped countries are frequent in large urban centres, where violence is common in societies with cultural, ethical, and moral principles deficiencies. Brazil faces a great wave of violence resulting from senseless public policies, corrupt politicians, and erroneous social values. These aggressions can result in important aesthetic-functional damages that incapacitate individuals and hamper their social interaction.

Among the various types of injuries that affect the maxillofacial region, perforating objects can result in doubtful prognosis due to the possibility of reaching vessels, nerves, and other key structures, causing haemorrhages, airways obstruction, brain damage, and death [1-3]. Knife injuries in the facial area are rare due to the reflex of selfdefence performed by the hands [4].

The objective of this report is to present a case of knife blade removal, who was not diagnosed in the primary evaluation, resulting in patient's ignorance regarding the problem and eyelid fistula after nine months. The blade penetrated the right orbital cavity bordering the area located between the lateral and inferior wall and was fixed close to the head of the mandible. The removal was performed under general anaesthesia with satisfactory outcome.

\section{CASE REPORT}

A 26-year-old brown male patient attended the outpatient clinic of the Buco-Maxillo-Facial Surgery and Traumatology Department of Santa Casa de Misericórdia, Anápolis-Goiás-Brazil with a major complaint of right eye pain. During anamnesis, the patient mentioned a history of physical aggression and loss of consciousness due to a frontal stroke that had occurred nine months before. He also reported that he had woken up at a local hospital with a face injury and was discharged after suturing performed by a physician without performing any imaging examination.

The patient also had an intense headache, difficulty in opening the mouth, chewing pain, tingling sensation, and different tactile sensation in the eye. He had a history of rhinitis and did not provide further important information. The clinical exam revealed mouth opening limitation with restriction on laterality movement.
The ophthalmological evaluation was done through the Rapid Ophthalmologic Evaluation, which consists of the external inspection of the eye, visual acuity test, red colour saturation, and brightness, pupillary function, and double vision test. All examinations showed a normal function with preserved ocular mobility and visual acuity. The periorbital tissue exhibited a small scar in the right infra-orbital region and the surface was hard on palpation.

In the face of the signs and symptoms evaluated, the first step was requesting a panoramic radiograph of the jaws and a postero-anterior radiography of the maxillary sinus.

The radiographs showed a radiopaque material similar to the active tip of a melee weapon (kitchen knife) inserted in an orbital region, with a posterior descending trajectory. After analysing the images, a computed tomography (CT) and angiotomography were requested, in addition to laboratory and ophthalmologic exams in order to obtain a three-dimensional visualisation of the object and determine the impact on key structures.

In the pre-operative consultation, a worsened palpebral aspect was observed with the formation of a fistula with pustular content and ocular dystopia (figure 1). The CT revealed a hyperdense object of $11 \mathrm{~cm}$, which was similar to a kitchen knife. It had entered into the right orbit

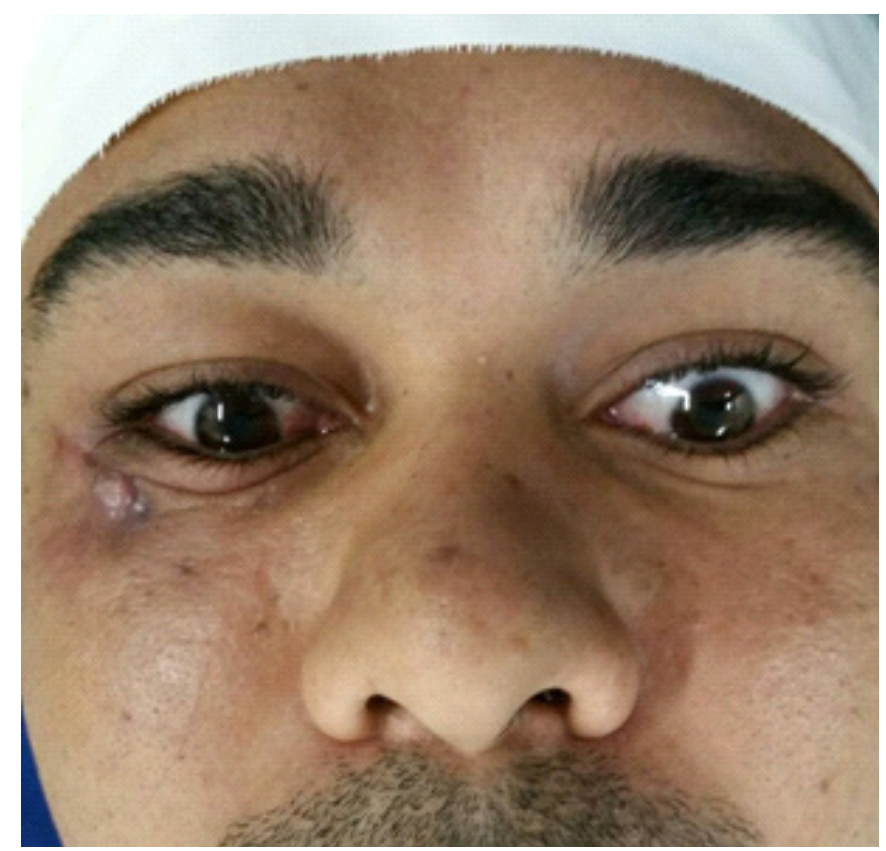

Figure 1. Front view of the patient in the second scheduled appointment. Observe localized palpebral fistulae. 
at the level of the orbital floor. It passed near the inferior orbital fissure, with exit trajectory through a fracture in the zygomatic bone and passage between the sphenoid bone, on the lateral lamina of the pterygoid process, infratemporal crest, and was medially located with respect to the zygomatic arch. There was also a hypodense area in the temporal bone and the head of the mandible, probably due to the trauma caused by the impact of the knife (figure 2). The arteriography indicated that the object was at a significant distance from vital structures, and the ophthalmological evaluation did not reveal changes in the visual system.

Due to the formation of the fistula, amoxicillin associated with potassium clavulanate was prescribed in a regimen of $500+125 \mathrm{mg}$ every eight hours, in order to perform a broad-spectrum antibiotic therapy.

The patient was submitted to general anaesthesia with orotracheal intubation. The subtarsal access was chosen and a flap was created in order to visualise the bone tissue and remove the cutaneous fistula. To that end,

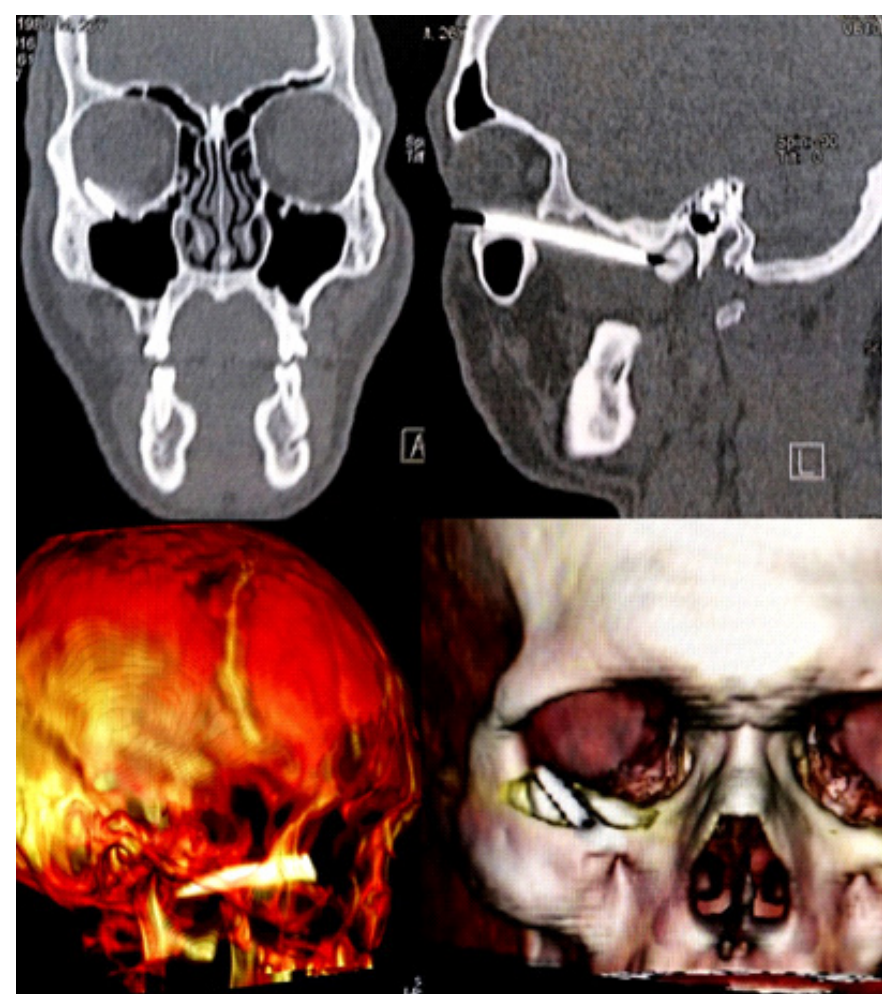

Figure 2. Imaging examinations show bone window CT. A - Coronal cut with presence of hyperdense material between lateral and inferior wall of the right orbit. B - Sagittal cut shows the trajectory of the melle weapon and the related area. C and D - Three-dimensional reconstruction shows the trajectory of the knife and surrounding tissues. the skin was incised using a No. 15 scalpel blade and the tissue was dissected through the orbicularis oculi muscle towards the infra-orbital border. After visualisation of the periosteum, it was incised with electrocautery, thus exposing the surface of the knife blade.

A continuous and delicate movement performed by the grasping of hemostatic forceps was responsible for the extraction of the object that exhibited mobility and rusty areas. The surgical wound did not exhibit abundant bleeding, only a few superficial blood vessels that were cauterised. The synthesis was performed using resorbable suture material (5-0 vicryl) in the orbicularis oculi muscle, and intradermal suture was performed using 5-0 nylon (figure 3). The 24-hour post-operative CT did not show signs of hematoma or lesions in the maxillofacial complex.

The patient was discharged after being hospitalised for 24 hours. He was clinically stable and did not exhibit neurological or ophthalmological damage. After thirty days, the patient exhibited a good recovery, with no deficit

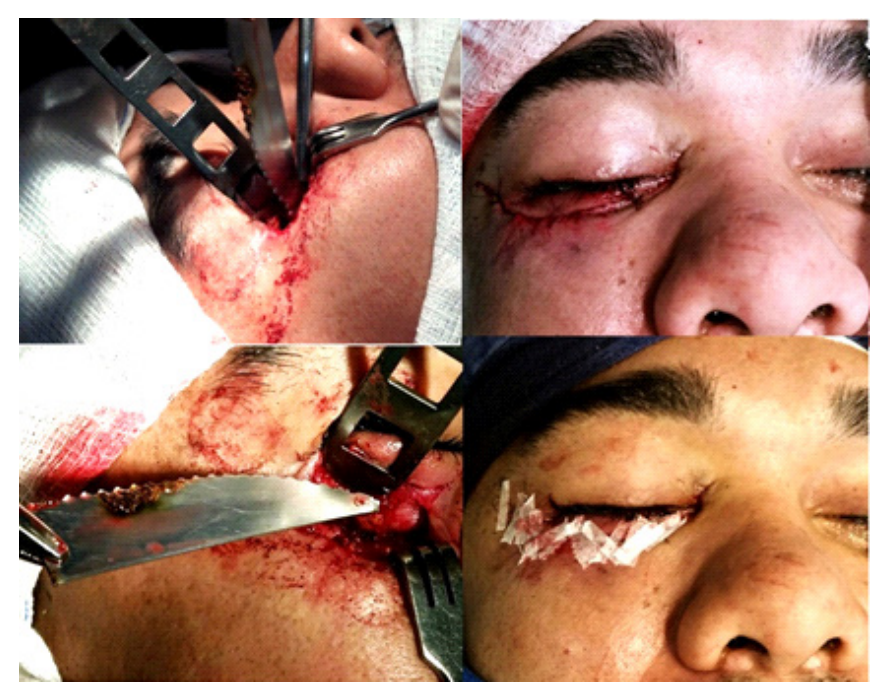

Figure 3. Removal of the knife blade through subtarsal access, continuous suture, and micropore dressing.

associated with the knife removal. Therefore, the treatment was discontinued (figure 4).

\section{DISCUSSION}

The management of penetrating injuries in the maxillofacial region depends on their nature and 


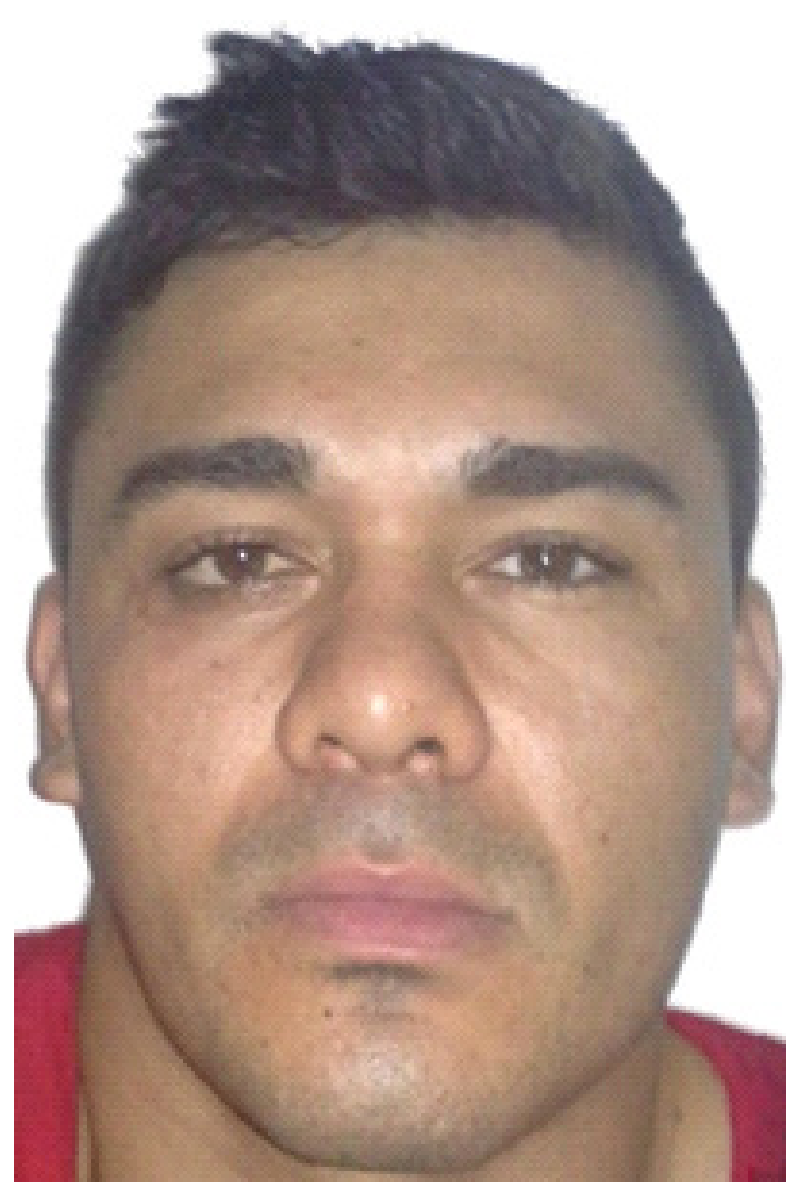

Figure 4. Thirty post-operative days after removal of the knife blade.

extent, type of weapon used, and anatomical structures affected. These injuries can have easy resolution or fatal consequences. However, it is widely accepted that initial treatment requires maintenance of the airways, control of possible bleeding, and accurate diagnosis $[5,6]$.

Several studies [1, 3, 5-9] have assessed accidents caused by perforating objects, such as knives, scissors, umbrella handles, hooks, arrows, firearm projectiles, forks, spoons, and twigs, among others. However, the case presented in our study seems to be the first one in which the patient had a melee weapon buried inside the bones of the face and not diagnosed in the first attendance.

It seems logical to believe that imaging should be used to evaluate the extent and trajectory of lesions caused by perforating objects, and correlate possible damages caused to anatomical structures, such as maxillary sinus, eyeballs, nerves, blood vessels, brain, and cervical vertebrae $[1,8]$.
Gussack and Jurkovich [6] have proposed an algorithm for diagnosis and treatment of penetrating wounds dividing the head into three areas and correlating the necessary evaluation examinations with the respective treatments. According to these authors, the case presented in our study would have required radiography in the initial urgency consultation, CT, angiography, and ophthalmologic evaluation.

In the case described, the knife blade probably broke during the blow. The patient lost consciousness. He woke up in the hospital and underwent the initial evaluation performed by another colleague. There was no projection of the handle of the knife, which possibly contributed to the error of the primary evaluation. Therefore, we emphasise the importance of a correct care protocol for soft tissue injuries and penetrating injuries.

According to the patient, he had never had radiographs taken, and was not even informed about the possibility of having a blade within his face. Amnesia in the face of a penetrating injury has been reported as an important symptom for requiring imaging tests, and was reported in $11.7 \%$ of the cases assessed in the study conducted by Exadaktylos, Stettbacher [3].

Scheepers and Lownie [10] have emphasised the role of angiography in the correlation of injuries with the proximity of the great vessels, thus preventing a possible trans-operative haemorrhage.

Careful removal of perforating objects should be performed, if possible, through the same entrance trajectory, avoiding a pendulum movement of the blade tip [2]. If trans-operative haemorrhage occurs, selective embolisation or vessel ligation may be considered during surgery [10]. In some cases, a multidisciplinary team is needed [11]. No functional changes, complications or sequels were observed in the post-operative period.

A late follow-up is important to evaluate ocular function against healing. The subtarsal approach, through percutaneous access, can generate a deficiency in the eyelid with the possibility of development of ectropion or entropion. The loss of orbital fat can develop diplopia.

This case demonstrates the difficulty in maintaining the principles required in the initial assessment of trauma patients, according to criteria established by emergency care guidelines. Exadaktylos et al [3] reported that loss of consciousness, seizure, neurological deficit, diagnosis of fracture by palpation or visualisation on the skull, 
and face radiography after an attack with a perforating instrument are mandatory indications for requesting CT. Also, it is very important to carefully inspect any cut before suturing tissue is done. The present case demonstrates an error of approach in urgent healthcare. Surprisingly, there were no major complications in the case described, but the consequences could have been fatal as a result of misconceptions caused by lack of resources, whether human, technical, or patrimonial.

\section{CONCLUSION}

Facial injuries should be evaluated with a rigid protocol in order to provide quality healthcare, thus minimising problems during the management of the cases. Imaging examinations should not be neglected, so that careful evaluation of the extent of the lesions and presence of foreign objects can be performed. Pre-operative examinations should be requested to evaluate regions that may be damaged during removal, thus improving the prognosis.

\section{Collaborators}

MAGS SILVA and MS FERREIRA, advised, designed, revised the theoretical assumptions and wrote the paper and documentation, preparation of figures. JE DIB, MS FERREIRA, MBE DIB and NEVES RG were responsible for performing the surgery and monitoring the hospitalized patient follow-up during the clinic case, checking record, collecting systemic data and for writing this paper.

\section{REFERENCES}

1. Bourguignon Filho $A M$, Puppin $A A$, Pimentel DP, Jaques PM, Borges $\mathrm{HO}$, Lanes Silveira $\mathrm{R}$, et al. Unusual penetrating orbit injury. International journal of oral and maxillofacial surgery. 2006;35(1):92-3. https://doi.org/10.1016/j.ijom.2005.04.018
2. Meer M, Siddiqi A, Morkel JA, Janse van Rensburg P, Zafar S. Knife inflicted penetrating injuries of the maxillofacial region: a descriptive, record-based study. Injury. 2010;41(1):77-81. https://doi.org/10.1016/j.injury.2009.05.003

3. Exadaktylos AK, Stettbacher A, Bautz PC. The value of protocol-driven CT scanning in stab wounds to the head. The American Journal of Emergency Medicine. 2002;20(4):295-7. https://doi.org/10.1053/ajem.2002.33784

4. Shinohara EH, Heringer L, Pereira de Carvalho J. Impacted knife injuries in the maxillofacial region: Report of 2 cases. Journal of Oral and Maxillofacial Surgery. 2001;59(10):1221-3. https://doi.org/10.1053/joms.2001.26730

5. Olasoji HO, Tahir AA, Ahidjo A, Madziga A. Penetrating arrow injuries of the maxillofacial region. The British journal of oral \& maxillofacial surgery. 2005;43(4):329-32. https://doi. org/10.1016/j.bjoms.2004.10.026

6. Gussack GS, Jurkovich GJ. Penetrating facial trauma: a management plan. South Med J. 1988;81(3):297-302.

7. Erisen L, Basut O, Coskun H, Hizalan I. An unusual penetrating facial injury due to a fishing-line sinker. Journal of oral and maxillofacial surgery : official journal of the American Association of Oral and Maxillofacial Surgeons. 2001;59(8):945-7. https://doi.org/10.1053/joms.2001.25045

8. Orbay AS, Uysal OA, lyigun O, Erkan D, Guldogus F. Unusual penetrating faciocranial injury caused by a knife: a case report. Journal of cranio-maxillo-facial surgery: official publication of the European Association for Cranio-MaxilloFacial Surgery. 97;25(5):279-81. https://doi.org/10.1016/S10 10-5182(97)80067-4

9. Carneiro JT, Jr., da Silva Tabosa AK, de Souza FJ, Jr., Shinohara EH. Orbitoethmoidal impacted injury by kitchen knife causing abducens nerve palsy. Oral Maxillofac Surg. 2011;15(2):107-8. https://doi.org/10.1007/s10006-010-0213-1

10. Scheepers A, Lownie $M$. The role of angiography in facial trauma: a case report. The British journal of oral \& maxillofacial surgery. 1994;32(2):109-10.

11. Gulati A, Srinivasan B, Hunter R, Flood TR. Penetrating knife injury to the frontal lobe - a case report. The Annals of The Royal College of Surgeons of England. 2010;92(6):e41-e2. https://doi.org/10.1308/147870810X12699662981672

Received on: 15/1/2019 Final version resubmitted on: 2/3/2019 Approved on: 2/4/2019 